\title{
molecules
}

ISSN 1420-3049

www.mdpi.com/journal/molecules

Review

\section{Insights into Animal and Plant Lectins with Antimicrobial Activities}

\section{Renata de Oliveira Dias ${ }^{1}$, Leandro dos Santos Machado ${ }^{1}$, Ludovico Migliolo ${ }^{1}$ and Octavio Luiz Franco 1,2,*}

1 SInova, Programa de Pós Graduação em Biotecnologia, Universidade Católica Dom Bosco, 79117-900 Campo Grande, MS, Brazil; E-Mails: diasrdo@gmail.com (R.O.D.); leomachadovet@gmail.com (L.S.M.); ludovico.migliolo@gmail.com (L.M.)

2 Centro de Análises Proteômicas e Bioquímicas, Pós-Graduação em Ciências Genômicas e Biotecnologia, Universidade Católica de Brasília, 70790-100 Brasília, DF, Brazil

* Author to whom correspondence should be addressed; E-Mail: ocfranco@gmail.com or ocfranco@ucdb.br; Tel.: +55-67-3312-3467; Fax:+55-61-3347-4797.

Academic Editor: Tzi Bun NG

Received: 7 November 2014 / Accepted: 22 December 2014 / Published: 5 January 2015

\begin{abstract}
Lectins are multivalent proteins with the ability to recognize and bind diverse carbohydrate structures. The glyco -binding and diverse molecular structures observed in these protein classes make them a large and heterogeneous group with a wide range of biological activities in microorganisms, animals and plants. Lectins from plants and animals are commonly used in direct defense against pathogens and in immune regulation. This review focuses on sources of animal and plant lectins, describing their functional classification and tridimensional structures, relating these properties with biotechnological purposes, including antimicrobial activities. In summary, this work focuses on structural-functional elucidation of diverse lectin groups, shedding some light on host-pathogen interactions; it also examines their emergence as biotechnological tools through gene manipulation and development of new drugs.
\end{abstract}

Keywords: lectin; carbohydrate; antimicrobial; animal defense; plant defense 


\section{Introduction}

Lectins are a complex group of proteins and/or glycoproteins of non-immune origin, possessing at least one non-catalytic domain which binds reversibly and specifically to monosaccharides, oligosaccharides and glycoconjugates. These proteins have also been named agglutinins or hemagglutinins and are found as monomers, homo- and heterodimers, as well as homo- and heterotetramer molecules, and they are widely distributed in Nature. Lectins are ubiquitous proteins and have been isolated from viruses, fungi, bacteria, invertebrates, unicellular organisms, animals and plants $[1,2]$.

The lectin binding sites on the carbohydrate, called the carbohydrate recognition domain (CRD), promote specific recognition in accordance with the key-lock model [3]. Besides the CRD, which is highly conserved in each type of lectin [4], specificity occurs throughout a series of weak chemical interactions [5-7]. The diversity of biological activities conferred by lectin-carbohydrate binding, as well as the molecular structure and specificity of lectins, means that these proteins form a large and heterogeneous group $[1,8,9]$. Lectins are considered as proteins with an estimated size from 60 to $400 \mathrm{kDa}$ [10]. However, some antimicrobial peptides present lectin-like activity, i.e., ability to recognize and bind carbohydrate-containing surface molecules [11,12] and sometimes are also considered as lectins [13].

Although plant lectins have been widely explored, the presence of lectins in animal sources has also been observed [14]. The roles of lectins include endocytosis and intracellular transport of vector glycoprotein mechanisms [15,16], induction of apoptosis in tumoral cells [17-19], blocking of HIV infection [20]; regulation of bacterial cell adhesion and migration [21] and control of protein levels in the blood [22]. Lectins are also known to play important roles in the immune system by recognizing carbohydrates that are found exclusively in pathogens, or that are inaccessible in host cells. The high diversity in the functions of lectins opens new prospects for their biotechnological use in multiple fields, including human and animal health as well as agribusiness. This work focuses on a review of plant and animal lectin distribution, function and structural characterization, highlighting their functional role in host defense and their further application in the development of biotechnological tools.

\section{Plant Lectins}

Lectins have been found in many plant groups, including mono- and dicotyledons, but most frequently they have been detected in Leguminoseae and Euphorbiaceae. Lectins are distributed in various tissues such as bark, bulb, fruit, latex, leaf, nodule, whole plant, phloem sap, rhizome, root, seed, stem, tissue culture, tuber, flowers and ovaries, and they have different cellular localizations and molecular properties [1,2]. Many plants contain lectins, including different food crops such as wheat, rice, potato, tomato, soybean and bean [2].

Plant lectins play an important role in defense mechanisms against the attack of microorganisms (Table 1) [1,23]. These lectins have been demonstrated to inhibit the growth of several phytopathogenic and non-pathogenic fungi [24-31]. The targets of some plant lectins are fungi that present chitin in their cell walls, resulting in inhibitory action on the growth and development of these microrganisms [1,25,27]. Plant lectins are also involved in defense against oomycetes. The role of 
these lectins in Phytophora infestans resistance is correlated with the presence of these proteins in a complex that recognizes the $\mathrm{INF}_{1}$ elicitor of Phytophthora infestans, transduces the hypersensitive response [32] and also strengthens the cell wall and plasma membrane (CW-PM) adhesion after infestation [33]. In fungal infections, different lectins are involved in Arabidopsis thaliana resistance [34-37]. The role of lectins in the antibacterial defense of $A$. thaliana is correlated with bacteria-mediated pattern-triggered immunity (PTI) [36] and with stomatal innate immunity, acting in the bacteria-mediated stomatal closure [37]. In the virus response, different plant lectins have been associated with the inhibition of the systemic spread of the tobacco etch virus [38] and with resistance in the primary and latter stages of potexvirus infection [39].

Table 1. Plant lectins showing antimicrobial activities.

\begin{tabular}{|c|c|c|c|}
\hline Family & Species & Defense against & Reference \\
\hline \multirow[t]{3}{*}{$\begin{array}{l}\text { Lectin Receptor } \\
\text { Kinases (LecRK) }\end{array}$} & Arabidopsis thaliana & $\begin{array}{l}\text { Fungi: Botrytis cinerea, Erysiphe } \\
\text { cichoracearum, Erysiphe orontii, Blumeria } \\
\text { graminis, Gigaspora rosea; } \\
\text { Oomycete: Phytophthora infestans; } \\
\text { Virus: Turnip mosaic and Cabbage leaf curl; } \\
\text { Bacteria: Pseudomonas syringae }\end{array}$ & {$[36,37,40,41]$} \\
\hline & $\begin{array}{c}\text { Nicotiana } \\
\text { benthamiana }\end{array}$ & Oomycete: $P$. infestans & [32] \\
\hline & Oryza sativa & Fungi: Magnaporthe grisea & [34] \\
\hline Amaranthins & Amaranthus viridis & Fungi: B. cincerea, Fusarium oxysporum & [42] \\
\hline Calreticulin/ & N. benthamiana & Oomycete: $P$. infestans & [43] \\
\hline calnexin & A. thaliana & Bacteria: $P$. syringae & [44] \\
\hline EUL-related lectins & O. sativa & $\begin{array}{l}\text { Bacteria: Xanthomonasoryzae pv. oryzae; } \\
\text { Fungi: Magnaporthe oryzae }\end{array}$ & [45] \\
\hline \multirow[t]{3}{*}{$\begin{array}{l}\text { Jacalin-related } \\
\text { lectins (JRLs) }\end{array}$} & Triticum aestivum & $\begin{array}{l}\text { Fungi: Fusarium graminearum, B. graminis } \\
\text { f. sp. Tritici, B. cinerea; } \\
\text { Oomycete: Phytophthora parasitica var } \\
\text { nicotianae; } \\
\text { Bacteria: P. syringe pv tabaci; } \\
\text { Virus: tobacco mosaic virus (TMV) } \\
\text { Fungi: F. graminearum, B. graminisf. sp. }\end{array}$ & [46-49] \\
\hline & A. thaliana & $\begin{array}{l}\text { Tritici, B.cinerea } \\
\text { Virus: tobacco etch virus; Plantago asiatica } \\
\text { mosaic virus (PlAMV) }\end{array}$ & {$[38,39,46,50-52]$} \\
\hline & O. sativa & Fungi: M.grisea & {$[52]$} \\
\hline Nictaba-related & A.thaliana & $\begin{array}{l}\text { Fungi: A. flavus, Fusarium moniliforme, } \\
\text { Fusarium solani, Rhizoctonia solani and } \\
\text { Trichoderma harzianum } \\
\text { Virus: Cucurbit aphid-borne yellows virus }\end{array}$ & $\begin{array}{l}{[50]} \\
{[53]}\end{array}$ \\
\hline Ricin-B & $\begin{array}{l}\text { Transgenic } N \text {. } \\
\text { benthamiana }\end{array}$ & Virus: tobacco etch virus & {$[54,55]$} \\
\hline
\end{tabular}


The most accepted classification of the plant lectins was the one presented by Van Damme et al. [2,56]. These authors divided the plant lectins into seven structurally and evolutionarily related protein families and, more recently, they included new proteins and redistributed the lectins in 12 families with different carbohydrate binding domains [56]. Recently, Lannoo and Van Damme [57] detailed seven of the best known lectin groups, dividing them into membrane-bound and soluble proteins with a lectin domain. Membrane-bound lectins include lectin receptor kinases (LecRK), and soluble proteins include amaranthins, calreticulin/calnexin, EUL-related lectins, jacalin-related lectins (JRLs), nictaba-related lectins and ricin-B lectins [57]. All of these classes were reported to be involved in antimicrobial defense (Table 1).

Lectin receptor kinases (LecRKs) are composed of two domains separated by a transmembrane region: an N-terminal extracellular lectin domain and a C-terminal cytosolic kinase domain. LecRK proteins are typically classified into three types: G-, C- and L-type [58,59], based on their lectin domain composition in the N-terminal region (i.e., similar to Galanthus nivalis agglutinin-GNA, calcium-dependent and legume-like lectins, respectively). Seventy-five LecRK genes (32 G-, 42 L- and 1 C-type) were identified in the Arabidopsis thaliana genome, while 173 genes ( 72 L-, 100 G- and 1 C-type) were identified in the rice genome [59]. Several LecRK genes were observed responding to abiotic and biotic stimuli in Arabidopsis thaliana [37,40,41]. The L-type LecRKs are involved in resistance to bacteria [37], oomycetes [32,33] and fungi [35].

The amaranthin lectin group encompasses the original protein found in the seeds of Amaranthus caudatus [60] and similar proteins from other plant species. The specificity of amaranthin for the carcinoma-associated $\mathrm{T}$ - and cryptic $\mathrm{T}$-antigens (Thomsen-Friedenreich antigen) has made these proteins a specific carcinoma marker [61,62]. In plant defense, amaranthin showed clear effects on aphids, in which it induced significant mortality [63] and reduced the population growth when present in transgenic cotton [64] and potato [65]. Besides the well-known antiproliferation role, the lectin from Amaranthus viridis Linn seeds also presents antifungal activity, inhibiting the growth of the phytopathogenic fungi Botrytis cincerea and Fusarium oxysporum [42].

Moreover, there are lectins located in sub-celullar organelles. For example, the endoplasmic reticulum (ER) presents two homologue lectins with a chaperone role: the membrane-bound calnexin (CNX) and the soluble calreticulin (CRT) protein [66]. They act together with other proteins promoting folding and quality control of glycoproteins in the ER [66]. Moreover, CRT is also involved in $\mathrm{Ca}^{2+}$ homeostasis in plant cells [67], abiotic stress response [68,69], plant immunity [44] and resistance to nematodes [70] and bacteria [44].

The Euonymus lectin-like (EUL) domain is widespread in plants, indicating the universal role of this lectin group in these organisms [71,72]. However, despite their wide distribution inside plants, these proteins were only recently described as a particular lectin group [73]. This EUL domain was shown to represent a conserved structural unit of a novel family of putative carbohydrate-binding proteins [71]. Although its agglutinative function was known [74-76], this lectin could not be classified into any of the known lectin families due to a lack of sequence information. These proteins are located in the nucleocytoplasmic compartment of the plant cells and present different specificities for diverse carbohydrate structures, depending on the protein and species studied $[45,73,77]$. Moreover, these proteins can be composed of a single domain (type S) or two tandem domains 
(type D) [45]. Rice EUL-related lectin genes were observed as up-regulated after abiotic stress (ABA and $\mathrm{NaCL}$ treatment) and down-regulated in fungus (Magnaporthe oryzae) infection [45].

Additionally, jacalin-related lectins (JRLs) are a group of plant lectins with one or more domain that is homologous to the jacalin protein. There are two subfamilies of JRLs: galactose-binding and mannose-binding jacalins [56]. Galactose-binding jacalins reside in the vacuolar and mannose-binding in the nucleocytoplasmic compartment of the plant cell [78]. Galactose-specific JRLs have been described in the family Moraceae, whereas the mannose-specific JRLs are common in Viridiplantae [56]. The jacalin-related lectin genes have been shown to be associated with disease resistance, abiotic stress signaling, wounding, insect damage or multiple stresses [79].

Similarly to JRLS, nictaba plays a role in certain regulatory and cell signaling pathways in plants $[80,81]$. Nictaba is produced in the tobacco plant after exposure to the plant hormone jasmonic acid methyl ester [80] as well as after insect herbivory [82]. Jasmonates are important signaling molecules for plant responses to abiotic and biotic stresses, as well as in plant development. They regulate induced defense mechanisms in plants after insect attack and wound response in general [83]. The accumulation of nictaba is not only confined to the leaf subjected to jasmonate treatment or insect herbivory, but can also be observed in other leaves of the tobacco plant, indicating a systemic response [84].

Another lectin involved in plant defense signaling is ricin. Ricin is included in the lectin family ricin-B, which has biological activity and toxicity in plants. Ricin-B related proteins accumulate in the plant vacuole or are secreted to the extracellular space [56]. This lectin can play a role in plant defense against pathogens [55,85] and insects [86,87]. Although there are studies describing the antiviral activity of this lectin $[54,55,85]$, its function has not yet been elucidated.

\section{Animal Lectins}

Animal lectins present an important role in host defense against microorganisms (Table 2). Their role in fungal defense is correlated with the control of host responses [88]. In antibacterial defense, lectins are correlated with pore-forming activity, which causes bacterial membrane permeabilization [89]. Some lectins present specificity for Gram-positive and not for Gram-negative bacteria, due to the inhibition of pore activity by lipopolysaccharides [89]. Moreover, lectins present a significant role in the host's defense against pathogens, by activating antibacterial autophagy [90] and vacuole lysis [91]. In viral infections, lectins are involved in binding and inhibiting pervasion and replication [50,92,93], and detect the pathogen-associated molecular patterns (PAMPs) of the viruses [94]. In contrast, some viruses can proliferate due to the presence of lectins [95]. 
Table 2. Animal lectins showing antimicrobial activities.

\begin{tabular}{cccc}
\hline Family & Species & Pathogen & Reference \\
\hline Calnexin/ & Marsupenaeus japonicus & Bacteria: Vibrio anguillarum & {$[96]$} \\
Calreticulin & Branchiostoma japonicum & Bacteria: Escherichia coli; & {$[97]$} \\
& Ictalurus punctatus & Bacteria: Edwardsiella ictaluri & {$[98]$} \\
& Marsupenaeus japonicus & Bacteria: Vibrio anguillarum & {$[92]$} \\
L-type & & Bacteria: Staphylococcus aureus; & \\
& Eriocheir sinensis & Vibrio parahaemolyticus; & {$[99]$} \\
C-type & Homo sapiens & Aeromonas hydrophila & \\
& Homo sapiens & Bacteria: Listeria monocytogenes & {$[89]$} \\
& Mus musculus & Fungi: Candida albicans & {$[100]$} \\
& & & {$[88,101]$} \\
\hline
\end{tabular}

The first attempt to divide the animal lectins into functional categories placed them in two main groups: the C-type ( $\mathrm{Ca}^{2+}$-dependent) and S-type lectins (thiol-dependent) [102]. However, with the increase in the number of described sequences, this classification changed and included several new groups [14]. Animal lectins present at least 25 different types of fold, including C-type, I-type (Ig fold), P-type, $\beta$-sandwich (jelly-roll, present in gallectins), calnexin/calreticulin, ERGIC-53 (endoplasmatic reticulum-Golgi intermediate compartment-53-L-type), G-domains of the LNS family (laminin, agrin), $\beta$-trefoil, cysteine-rich domain of C-type macrophage mannose receptor, fibrinogen-like domain (ficolins), intelectins and tachylectin-5 (reviewed in [103]). Some of these lectin groups have been proposed as being involved in antimicrobial resistence (Table 2). However, until now, some animal lectins have not presented the antimicrobial response described, but are recognized as involved in other relevant activities, such as antitumoral factors [17].

Like their plant homologues (described in Section 2), the animal-source proteins calreticulin (Crt) and calnexin $(\mathrm{Cnx})$ are homologous lectins that interact with synthesized glycoproteins in the endoplasmic reticulum (ER) and serve as molecular chaperones during folding and quality control [104]. In these organisms, Cnx and Crt also have important functions in phagocytosis [105] and apoptotic processes induced by ER stresses [106], as well as being related to viral infection [107-109].

In relation to L-type lectins (LTLs), these lectin domains have been found in leguminous plant seeds containing luminal carbohydrate recognition domains [110]. In humans and other mammals there are four L-type lectins, the first with an intermediate compartment of $53 \mathrm{kDa}$ (ERGIC-53), the second ERGIC-53-like (ERGL), the third being a vesicular integral membrane protein of $36 \mathrm{kDa}$ (VIP36), and the fourth considered VIP36-like (VIPL) [111-114]. These type I membrane proteins are involved in glycoprotein sorting, trafficking and targeting in luminal compartments of animal cells [115,116] also assisting in the blood coagulation process [117-121]. LTLs therefore have an important role as pattern recognition receptors in the immune system. LTLs can be induced after bacterial infection with lipopolysaccharides (LPS) and peptidoglycans (PGN). These lectins can agglutinate bacteria in a calcium-dependent manner or by opsonization, binding to the surface glycoconjugates of these microorganisms [98,99,122].

The C-type lectin family includes a superfamily of proteins containing the C-type lectin domain (CTLD). Largely described in the Metazoa group, today this group is also associated with sequences 
from other Eukarya and species of bacteria and viruses. This group encompasses the most diverse category of lectins, with several sub-groups described. The lectin $\mathrm{C}$ subgroups include at least 17 classes of proteins [123]. These proteins have functions from the most basal and common role $-\mathrm{Ca}^{2+}$-dependent carbohydrate binding - to the most developed roles, such as specifically recognizing protein, lipid and inorganic ligands [123]. C-type lectin receptors (CLRs) are a group of pattern recognition receptors (PRRs) that recognize carbohydrate structures in microbes as pathogen-associated molecular patterns (PAMPs). They are expressed mainly in dendritic cells (DCs) and macrophages [124].

Furthermore, the S-type lectin group was replaced by the galectin group, composed of structural homologues of CRDs, which typically bind glycoconjugates containing beta-galactose. These proteins are mainly expressed in cells from the immune system and in the epithelial cells. Galectins are involved in the recognition of endogenous carbohydrate ligands and also in the binding of glycans on the surface of microorganisms [125]. Galectins present a significant role in the host's defense against bacteria $[90,91]$.

Finally and no less importantly, the sialic-recognizing Ig-superfamily lectins (Siglecs) constitute the major subfamily of the I-type lectin group (proteins presenting an immunoglobulin (Ig)-like domain that mediates the glycan recognition) [126]. Siglecs have been associated with intracellular signaling and immune response [126,127] and are proposed as a novel pharmacological strategy for immunotherapy and glycotherapy due to their action on cell death, anti-proliferation effects and other cell activities [128]. Siglecs are involved in the host-pathogen interaction, in which the protein was observed as mediating the recognition of sialylated glycans expressed in the lipooligosaccharides [129] and inducing rapid proinflammatory cytokine and type I IFN responses to Campylobacter jejuni [130]. Siglecs are positive and negative regulators of the immune system and are reported as being involved in resistance and/or susceptibility to pathogens [131].

\section{Lectin Structural Analyses}

The plant lectins are constituted by several families which have very conserved recognition sites. Several lectin structures have already been solved by X-ray diffraction, among which ConA from Canavalia virosa is a typical prototype. ConA lectin crystallization was previously described in 1936, being the first hemagglutinin isolate with high toxic activity evaluated in rabbits [132]. Furthermore, other lectins have already been elucidated, such as ricin, a lectin from Ricinus communis, which exhibited a combination of $\alpha$-helices and $\beta$-sheets [2]. Oliveira and coworkers [133] also demonstrated a similar scaffold for a lectin purified from Caesalpinia tinctoria [133]. In most, the tertiary structure conformation of lectins presents structurally dominant $\beta$-sheets combined with the presence of $\alpha$-helices that can also be absent. In spite of lectins' wide structural diversity, at least one specific site for the carbohydrate link in each polypeptide chain was observed. Lectin-carbohydrate interactions present a carbohydrate recognition domain which might be localized on the surface of the protein molecule, as observed in lectins from Fabaceae [134]. In the active site for carbohydrate ligand the interaction patterns are guided by hydrogen bonds needed for lectin-carbohydrate complex formation. Several studies about the specificity of carbohydrate and plant lectins have revealed that most do not present affinity to monosaccharides. This lesser affinity may also be observed in some red algal lectins which bind to glycoproteins, having no requirement for divalent cations and presenting low molecular 
masses [135]. Furthermore, plant lectins are commonly encountered in monomeric, dimeric, trimeric and tetrameric forms. For example, monomeric forms of lectins were observed in Hevea brasiliensis and in arcein from Phaseolus vulgaris L. (Figure 1A) [136,137]. Dimeric lectins are also observed, and these are subdivided into homo- and heterodimeric. Homodimerism is seen in Erythrina speciosa Andr. and Amaranthus caudatus lectin (amaranthin) (Figure 1B) [60,138]. Conversely, Ricinus communis demonstrated two different chains with subunits of 29.5 and $28.5 \mathrm{kDa}$ bonded by one disulfide bond [139]. This heterodimeric lectin, also called ricin, consists of two subunits, namely the A chain showing hydrolitic activity linked to a B chain, involved in carbohydrate binding (Figure 1C) [140]. Trimeric lectins are observed in the red marine alga, Ptilota filicina, which presents molecular masses of around $56.9 \mathrm{kDa}$ by gel filtration divided into three subunits of $19.3 \mathrm{kDa}$, indicating three identical subunits [141]. In turn, jacalin presented a tetramer structure, which also has four lectin domains (Figure 1D) [142]. Another interesting structural feature indicates that carbohydrate binding activity could be improved in the presence of some ions. This common facet observed in the lectin group demonstrated the presence of two important ions, $\mathrm{Ca}^{2+}$ and $\mathrm{Mn}^{2+}$, which are essential for sugar binding. The amino acids involved in ion binding are highly conserved throughout legume lectins. L-type lectins, for example, present an oligomeric structure in which the monomers consist of antiparallel $\beta$-sheets disposed in flat strands. Some of these lectin groups demand $\mathrm{Ca}^{2+}$ and transition metal ions (usually $\mathrm{Mn}^{2+}$ ) for their carbohydrate-binding activity [143]. Kabir and coworkers [144], for example, revealed that lectin from Pisum sativum L. presents interesting pharmacological activities and is of great interest in biomedical research. Recent studies demonstrated that pea lectin inhibited Ehrlich ascites carcinoma cells. In addition, this lectin also demonstrated activity in vivo, causing $63 \%$ and $44 \%$ growth inhibition of the carcinoma cells in mice when administered at 2.8 and $1.4 \mathrm{mg} / \mathrm{kg} /$ day, respectively [144].

In contrast, animal lectins have been elucidated according to their 3D structure. Galectins present a similar CRD, which is folded into two antiparallel $\beta$-sheets that are slightly curved, forming a concave ligand-binding site (PFAM: 00337-Galactoside-binding lectin, Figure 1E) with specificity for glycans containing $\beta$-galactoside [145]. Calnexin and calreticulin present two distinct structural regions: a globular lectin domain and a proline-rich P-domain inserted between the $\mathrm{C}$ - and $\mathrm{N}$-terminal domains [146]. The lectin domain of both these proteins (CNX and CRT) is composed of two curved $\beta$-sheets, which form a $\beta$-sandwich, similar to the legume lectin domain (Figure 1F) [147]. Moreover, these proteins also present a calcium-binding site, which seems to be mainly involved with structural requirements rather than in the ligand binding [148]. The biological activity in the presence of divalent ions is explained due to structural modification that its ions promoted in the lectins, causing recognition in the carbohydrate, stabilizing the ligand site and directing the amino acid's spatial position in the carbohydrate ligand. In contrast, the lectins that do not need ions already present the correct structural conformation for carbohydrate recognition [149]. Additionally, L-type animal lectins (Figure 1G) also present a legume-like lectin domain and calcium binding. However, in contrast with the calreticulin, the structural characterization of the Homo sapiens LMAN1 protein indicates a correlation between the calcium-binding and the lectin domain activity, in which the ligand could be released with changes in the $\mathrm{Ca}^{2+}$ concentration [150]. The calcium requirement is also strong when correlated with the animal C-type lectin family. The human lung surfactant protein D presents three calcium-dependent lectin domains bonded by an $\alpha$-helical coiled-coil neck (Figure 1H) [151]. 
(A)

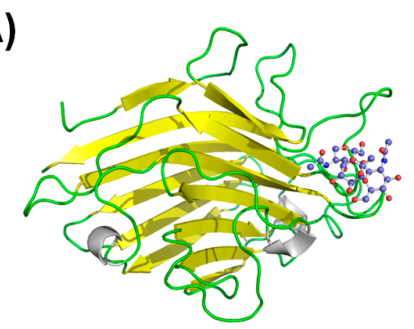

(C)

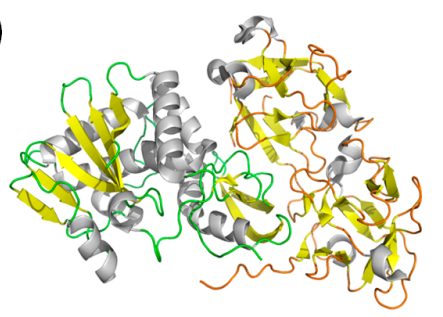

(E)

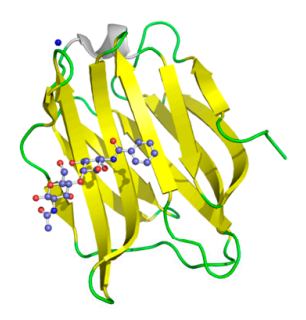

(G)

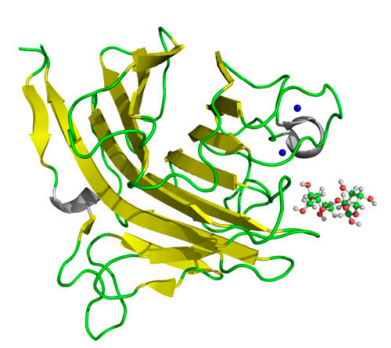

(B)

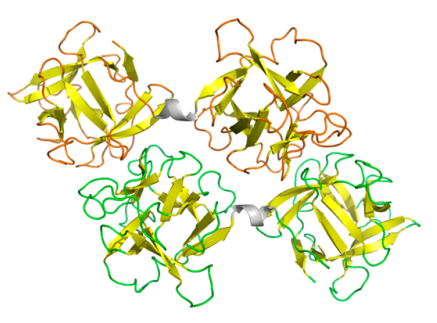

(D)

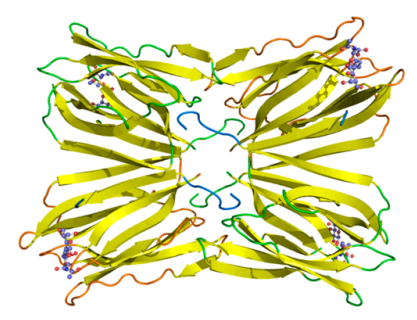

(F)

(H)
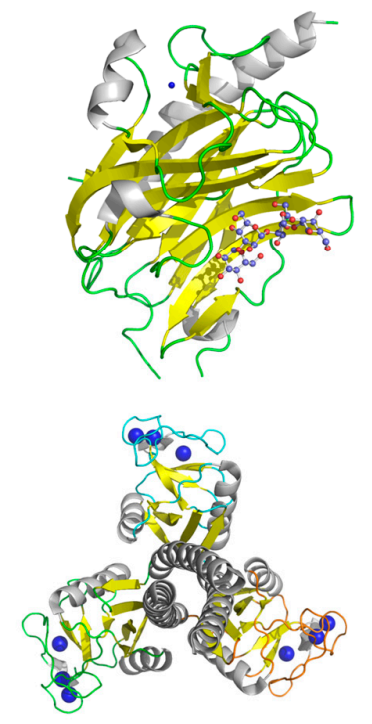

Figure 1. Lectin tridimensional structures in (A) arcein from Phaseolus vulgaris L. (pdb: 1ioa) [152]; (B) amaranthin from Amaranthus caudatus (pdb: 1jly) [138]; (C) ricin from Ricinus communis (pdb: 3rti) [140]; (D) jacalin from Artocarpus integer (pdb: 1m26) [142]; (E) galectin-3 from Homo sapiens (pdb: 2xg3) [145]; (F) calreticulin from Mus musculus (pdb: 3o0w) [147]; (G) Homo sapiens L-type (pdb: 4gkx) [150] and (H) Homo sapiens C-type (pdb: 1pwb) [151]. The colors yellow and white represented the secondary structures of $\beta$-sheet, $\alpha$-helices in lectins, respectively. In addition, blue represents the $\mathrm{Ca}^{2+}$ ion and carbohydrates are represented in ball and stick.

\section{Biotechnological Potential}

The use of a myriad of lectins as biotechnological tools has been presented by many researchers in recent years, especially due to their enormous ability to discriminate sugars with high specificity. Plant and animal lectins show rich hydrophobic amino acid regions composed of deep pocket forms. Such hydrophobic pockets allow a number of interactions between lectins and distinct carbohydrates, conferring multiple functions that include the antimicrobials described here [42,153-155]. Studies with 42 plant lectins carried out by Barre and coworkers [156] revealed that $32 \%$ of the hydrophobic pockets are identical, suggesting a clear structural conserved conformation [156]. Nevertheless, the 
development of antibiotics from lectins is a real challenge, since their production is expensive and complicated for chemical synthesis due to the complex structural scaffold and the high number of disulphide bonds. One option is the production of heterologous systems, including bacterial vectors such as E. coli or B. subtilis, or yeast vectors such as different Pichia species. However, since there are lectins that showed bactericidal or fungicidal effects, a selective strategy must be performed in order to prevent the activity of antimicrobial lectins against the host expression vector [157].

Another option consists of producing these lectins by using genetically modified plants [157]. Agricultural losses are a challenging economic and food security problem. Global food security is threatened by population growth and the emergence and spread of crop pests, which is significantly increasing with climate change [158]. Strategies to overcome the damage caused by pathogens include chemical treatment, conventional breeding and transgenic approaches [159]. Beginning in 1980, new strategies for pest control, such as integrated pest management (IPM) and the use of transgenic crops have been proposed and tested, to avoid these crop production losses. Transgenic plants expressing lectin genes have been shown to confer resistance against nematodes and insects. The expression of lectins acts in partial resistance to nematodes in transgenic plants $[23,160]$ and they have the capacity to reduce galling caused by nematodes when these are introduced in the soil $[23,161,162]$. The exact mechanism of action of lectins against nematodes has not been well elucidated.

The insecticidal activity of different lectins has also been observed [163,164]. The effects of lectins when ingested by insect larvae are in growth inhibition, reduction of size and weight gain, interference in the fecundity of the female, as well as in reducing pupation and the percentage of adult emergence, increasing the total development time, and in some cases resulting in the death of the insect larvae [165-169]. Morover, some transgenic plants expressing lectins also show some resistance against multiple pathogens $[49,170]$. In this case, a soybean lectin (SBL) was introduced into tobacco plants via Agrobacterium-mediated transformation, improving resistance to infection by Phytophthora nicotianae [163]. Another example is the expression of the agglutinin gene from Pinellia ternata in tobacco chloroplasts [171]. Such genetic engineering has conferred wide resistance against whitefly, aphids, Lepidopterans and bacterial and viral pathogens. The virus infections have also been focused as a target for transgenic plants synthesizing lectins. Heterologous expression of a jacalin-type lectin (JAX1) in Nicotiana benthamiana was capable of interfering with potexvirus infection [39].

Therefore, lectins can be used not only in transgenic plant development. There are some reports describing the use of different lectins for evaluation of cell surfaces [172,173], for blood typing [174,175], as mitogenic agents [176-180], to detect changes in cellular transformation [181,182], in the clearance of sulfated glycoprotein hormones, control of glycoprotein biosynthesis, cell-cell interactions in the immune system [183] and associated with susceptibility and severity in a wide variety of infectious and autoimmune diseases [184,185]. Moreover, lectins can also be applied in laboratory and chemical analyses $[173,178,186]$, since they are easily immobilized on inert supports [173,187].

In the antitumor field Helix pomatia agglutinin (HPA), initially isolated from Roman snails, has been used extensively in histopathology, since its binding to tissue sections from breast and colon cancers is correlated with the worst prognosis for patients. HPA recognizes $\alpha$-D- $N$-acetylgalactosamine ( $\alpha$-Gal-NAc) containing epitopes which are only present in cancer cell lines. The crystal structures of the lectin complexed with two Gal-Nac-containing epitopes associated with cancer, the Tn ( $\alpha$-Gal-NAc-Ser) and Forssman ( $\alpha$-Gal-NAc-1-3-Gal-NAc) antigens, show that lectin's specificity 
for GalNAc is due to a particular network of hydrogen bonds. A histidine residue makes hydrophobic contact with the aglycon, rationalizing the preference for GalNAc bearing an additional sugar or amino acid in the alpha position [188]. Furthermore, Mus musculus galectin-1 (MMG) isolated from mouse has been shown to attenuate experimental acute and chronic inflammation. MMG recognizes $\beta$-galactoside $(\beta-\mathrm{Gal})$, and experiments have demonstrated that it may be part of a novel anti-inflammatory loop [189].

\section{Conclusions}

In summary, lectins from animal and plant sources have a remarkable repertoire of compounds that not only bind to carbohydrates, but also open novel and unusual possibilities for biotechnology. They are indeed a promising source of natural tools that could bring several benefits to agribusiness and human health. In this context, a combination of bioprospection, structural and molecular biology and genetic engineering will bring real discoveries in the near future.

\section{Acknowledgments}

This work was supported by CNPq, CAPES, FAPDF and FUNDECT.

\section{Author Contributions}

R.O.D. and O.L.F. were involved in all parts of this manuscript, L.S.M. was involved in describing animal lectins and L.M. was responsible for the topic on structures.

\section{Conflicts of Interest}

The authors declare no conflict of interest.

\section{References}

1. Peumans, W.J.; Vandamme, E.J.M. Lectins as plant defense proteins. Plant Physiol. 1995, 109, 347-352.

2. Van Damme, E.J.M.; Peumans, W.J.; Barre, A.; Rouge, P. Plant lectins: A composite of several distinct families of structurally and evolutionary related proteins with diverse biological roles. Crit. Rev. Plant Sci. 1998, 17, 575-692.

3. Kennedy, J.F.; Palva, P.M.G.; Corella, M.T.S.; Cavalcanti, M.S.M.; Coelho, L. Lectins, versatile proteins of recognition-A review. Carbohydr. Polym. 1995, 26, 219-230.

4. Ni, Y.; Tizard, I. Lectin-carbohydrate interaction in the immune system. Vet. Immunol. Immunopathol. 1996, 55, 205-223.

5. Sharma, V.; Surolia, A. Analyses of carbohydrate recognition by legume lectins: Size of the combining site loops and their primary specificity. J. Mol. Biol. 1997, 267, 433-445.

6. Weis, W.I.; Drickamer, K. Structural basis of lectin-carbohydrate recognition. Ann. Rev. Biochem. 1996, 65, 441-473.

7. Kompella, U.B.; Lee, V.H.L. Delivery systems for penetration enhancement of peptide and protein drugs: Design considerations. Adv. Drug Deliv. Rev. 2001, 46, 211-245. 
8. Peumans, W.J.; van Damme, E.J.M. Plant lectins: Versatile proteins with important perspectives in biotechnology. Biotechnol. Genet. Eng. Rev. 1998, 15, 199-228.

9. VanDamme, E.J.M.; Barre, A.; Rouge, P.; VanLeuven, F.; Balzarini, J.; Peumans, W.J. Molecular cloning of the lectin and a lectin-related protein from common solomon's seal (polygonatum multiflorum). Plant Mol. Biol. 1996, 31, 657-672.

10. Da Silva, L.C.; Correia, M.T. Plant lectins and toll-like receptors: Implications for therapy of microbial infections. Front. Microbiol. 2014, 5, doi:10.3389/fmicb.2014.00020.

11. Wang, W.; Owen, S.M.; Rudolph, D.L.; Cole, A.M.; Hong, T.; Waring, A.J.; Lal, R.B.; Lehrer, R.I. Activity of alpha- and theta-defensins against primary isolates of hiv-1. J. Immunol. 2004, 173, 515-520.

12. Ahmad, S. First line of defence? Nat. Rev. Microbiol. 2005, 3, 831-831.

13. Wang, W.; Cole, A.M.; Hong, T.; Waring, A.J.; Lehrer, R.I. Retrocyclin, an antiretroviral theta-defensin, is a lectin. J. Immunol. 2003, 170, 4708-4716.

14. Kilpatrick, D.C. Animal lectins: A historical introduction and overview. Biochim. Biophys. Acta 2002, 1572, 187-197.

15. Yi, S.M.P.; Harson, R.E.; Zabner, J.; Welsh, M.J. Lectin binding and endocytosis at the apical surface of human airway epithelia. Gene Ther. 2001, 8, 1826-1832.

16. Yamamoto, K. Intracellular lectins involved in folding and transport in the endoplasmic reticulum. Biol. Pharm. Bull. 2009, 32, 767-773.

17. Bah, C.S.; Fang, E.F.; Ng, T.B.; Mros, S.; McConnell, M.; Bekhit Ael, D. Purification and characterization of a rhamnose-binding chinook salmon roe lectin with antiproliferative activity toward tumor cells and nitric oxide-inducing activity toward murine macrophages. J. Agric. Food Chem. 2011, 59, 5720-5728.

18. Fang, E.F.; Ng, T.B. Antitumor Potential and Other Emerging Medicinal Properties of Natural Compounds; Springer: Dordrecht, The Netherlands, 2013.

19. Kim, M.; Rao, M.V.; Tweardy, D.J.; Prakash, M.; Galili, U.; Gorelik, E. Lectin-induced apoptosis of tumor-cells. Glycobiology 1993, 3, 447-453.

20. Tanaka, H.; Chiba, H.; Inokoshi, J.; Kuno, A.; Sugai, T.; Takahashi, A.; Ito, Y.; Tsunoda, M.; Suzuki, K.; Takénaka, A. Mechanism by which the lectin actinohivin blocks hiv infection of target cells. Proc. Natl. Acad. Sci. USA 2009, 106, 15633-15638.

21. Tanne, A.; Neyrolles, O. C-type lectins in immune defense against pathogens: The murine dc-sign homologue signr3 confers early protection against mycobacterium tuberculosis infection. Virulence 2010, 1, 285-290.

22. Rydz, N.; Swystun, L.L.; Notley, C.; Paterson, A.D.; Riches, J.J.; Sponagle, K.; Boonyawat, B.; Montgomery, R.R.; James, P.D.; Lillicrap, D. The c-type lectin receptor clec4m binds, internalizes, and clears von willebrand factor and contributes to the variation in plasma von willebrand factor levels. Blood 2013, 121, 5228-5237.

23. Ripoll, C.; Favery, B.; Lecomte, P.; van Damme, E.; Peumans, W.; Abad, P.; Jouanin, L. Evaluation of the ability of lectin from snowdrop (Galanthus nivalis) to protect plants against root-knot nematodes. Plant Sci. 2003, 164, 517-523.

24. Van Parijs, J.; Broekaert, W.F.; Goldstein, I.J.; Peumans, W.J. Hevein: An antifungal protein from rubber-tree (Hevea brasiliensis) latex. Planta 1991, 183, 258-264. 
25. Koo, J.C.; Lee, S.Y.; Chun, H.J.; Cheong, Y.H.; Choi, J.S.; Kawabata, S.; Miyagi, M.; Tsunasawa, S.; Ha, K.S.; Bae, D.W.; et al. Two hevein homologs isolated from the seed of Pharbitis nil L. Exhibit potent antifungal activity. Biochim. Biophys. Acta 1998, 1382, 80-90.

26. Xu, Q.; Liu, Y.; Wang, X.C.; Gu, H.Y.; Chen, Z.L. Purification and characterization of a novel anti-fungal protein from gastrodia elata. Plant Physiol. Biochem. 1998, 36, 899-905.

27. Ciopraga, J.; Gozia, O.; Tudor, R.; Brezuica, L.; Doyle, R.J. Fusarium sp. growth inhibition by wheat germ agglutinin. Biochim. Biophys. Acta 1999, 1428, 424-432.

28. Freire, M.D.M.; Gomes, V.M.; Corsini, R.E.; Machado, O.L.T.; de Simone, S.G.; Novello, J.C.; Marangoni, S.; Macedo, M.L.R. Isolation and partial characterization of a novel lectin from Talisia esculenta seeds that interferes with fungal growth. Plant Physiol. Biochem. 2002, 40, 61-68.

29. Damico, D.C.S.; Freire, M.G.M.; Gomes, V.M.; Toyama, M.H.; Marangoni, S.; Novello, J.C.; Macedo, M.L.R. Isolation and characterization of a lectin from Annona muricata seeds. J. Protein Chem. 2003, 22, 655-661.

30. Miyakawa, T.; Hatano, K.-I.; Miyauchi, Y.; Suwa, Y.-I.; Sawano, Y.; Tanokura, M. A secreted protein with plant-specific cysteine-rich motif functions as a mannose-binding lectin that exhibits antifungal activity. Plant Physiol. 2014, 166, 766-778.

31. Ang, A.S.W.; Cheung, R.C.F.; Dan, X.; Chan, Y.S.; Pan, W.; Ng, T.B. Purification and characterization of a glucosamine-binding antifungal lectin from Phaseolus vulgaris cv. Chinese pinto beans with antiproliferative activity towards nasopharyngeal carcinoma cells. Appl. Biochem. Biotechnol. 2014, 172, 672-686.

32. Kanzaki, H.; Saitoh, H.; Takahashi, Y.; Berberich, T.; Ito, A.; Kamoun, S.; Terauchi, R. NbLRK1, a lectin-like receptor kinase protein of Nicotiana benthamiana, interacts with Phytophthora infestans INF1 elicitin and mediates INF1-induced cell death. Planta 2008, 228, 977-987.

33. Bouwmeester, K.; de Sain, M.; Weide, R.; Gouget, A.; Klamer, S.; Canut, H.; Govers, F. The lectin receptor kinase LecRK-I.9 is a novel Phytophthora resistance component and a potential host target for a RXLR effector. PLoS Pathog. 2011, 7, e1001327.

34. Chen, X.; Shang, J.; Chen, D.; Lei, C.; Zou, Y.; Zhai, W.; Liu, G.; Xu, J.; Ling, Z.; Cao, G. A B-lectin receptor kinase gene conferring rice blast resistance. Plant J. 2006, 46, 794-804.

35. Huang, P.; Ju, H.-W.; Min, J.-H.; Zhang, X.; Kim, S.-H.; Yang, K.-Y.; Kim, C.S. Overexpression of L-type lectin-like protein kinase 1 confers pathogen resistance and regulates salinity response in Arabidopsis thaliana. Plant Sci. 2013, 203, 98-106.

36. Singh, P.; Chien, C.-C.; Mishra, S.; Tsai, C.-H.; Zimmerli, L. The arabidopsis lectin receptor kinase-VI. 2 is a functional protein kinase and is dispensable for basal resistance to Botrytis cinerea. Plant Signal. Behav. 2012, 8, e22611.

37. Singh, P.; Kuo, Y.-C.; Mishra, S.; Tsai, C.-H.; Chien, C.-C.; Chen, C.-W.; Desclos-Theveniau, M.; Chu, P.-W.; Schulze, B.; Chinchilla, D.; et al. The lectin receptor kinase-VI.2 is required for priming and positively regulates arabidopsis pattern-triggered immunity. Plant Cell 2012, 24, 1256-1270.

38. Chisholm, S.T.; Mahajan, S.K.; Whitham, S.A.; Yamamoto, M.L.; Carrington, J.C. Cloning of the Arabidopsis RTM1 gene, which controls restriction of long-distance movement of tobacco etch virus. Proc. Natl. Acad. Sci. USA 2000, 97, 489-494. 
39. Yamaji, Y.; Maejima, K.; Komatsu, K.; Shiraishi, T.; Okano, Y.; Himeno, M.; Sugawara, K.; Neriya, Y.; Minato, N.; Miura, C.; et al. Lectin-mediated resistance impairs plant virus infection at the cellular level. Plant Cell 2012, 24, 778-793.

40. Bouwmeester, K.; Govers, F. Arabidopsis L-type lectin receptor kinases: Phylogeny, classification, and expression profiles. J. Exp. Bot. 2009, 60, 4383-4396.

41. Desclos-Theveniau, M.; Arnaud, D.; Huang, T.-Y.; Lin, G.J.-C.; Chen, W.-Y.; Lin, Y.-C.; Zimmerli, L. The arabidopsis lectin receptor kinase LecRK-V.5 represses stomatal immunity induced by Pseudomonas syringae pv. Tomato DC3000. PLoS Pathog. 2012, 8, e1002513.

42. Kaur, N.; Dhuna, V.; Kamboj, S.S.; Agrewala, J.N.; Singh, J. A novel antiproliferative and antifungal lectin from amaranthus viridis linn seeds. Protein Pept. Lett. 2006, 13, 895-905.

43. Matsukawa, M.; Shibata, Y.; Ohtsu, M.; Mizutani, A.; Mori, H.; Wang, P.; Ojika, M.; Kawakita, K.; Takemoto, D. Nicotiana benthamiana calreticulin $3 \mathrm{a}$ is required for the ethylene-mediated production of phytoalexins and disease resistance against oomycete pathogen Phytophthora infestans. Mol. Plant Microbe Interact. 2013, 26, 880-892.

44. Qiu, Y.; Xi, J.; Du, L.; Roje, S.; Poovaiah, B.W. A dual regulatory role of arabidopsis calreticulin-2 in plant innate immunity. Plant J. 2012, 69, 489-500.

45. Atalah, B.A.; De Vleesschauwer, D.; Xu, J.; Fouquaert, E.; Höfte, M.; van Damme, E.J. Transcriptional behavior of EUL-related rice lectins towards important abiotic and biotic stresses. J. Plant Physiol. 2014, 171, 986-992.

46. Xiang, Y.; Song, M.; Wei, Z.; Tong, J.; Zhang, L.; Xiao, L.; Ma, Z.; Wang, Y. A jacalin-related lectin-like gene in wheat is a component of the plant defence system. J. Exp. Bot. 2011, 62, 5471-5483.

47. Ma, Q.-H.; Zhen, W.-B.; Liu, Y.-C. Jacalin domain in wheat jasmonate-regulated protein Ta-JA1 confers agglutinating activity and pathogen resistance. Biochimie 2013, 95, 359-365.

48. Gorlach, J.; Volrath, S.; KnaufBeiter, G.; Hengy, G.; Beckhove, U.; Kogel, K.H.; Oostendorp, M.; Staub, T.; Ward, E.; Kessmann, H.; et al. Benzothiadiazole, a novel class of inducers of systemic acquired resistance, activates gene expression and disease resistance in wheat. Plant Cell 1996, 8 , 629-643.

49. Ma, Q.-H.; Tian, B.; Li, Y.-L. Overexpression of a wheat jasmonate-regulated lectin increases pathogen resistance. Biochimie 2010, 92, 187-193.

50. Lee, J.R.; Boltz, K.A.; Lee, S.Y. Molecular chaperone function of arabidopsis thaliana phloem protein 2-a1, encodes a protein similar to phloem lectin. Biochem. Biophys. Res. Commun. 2014, $443,18-21$.

51. Chisholm, S.T.; Parra, M.A.; Anderberg, R.J.; Carrington, J.C. Arabidopsis RTM1 and RTM2 genes function in phloem to restrict long-distance movement of tobacco etch virus. Plant Physiol. 2001, 127, 1667-1675.

52. Qin, Q.M.; Zhang, Q.; Zhao, W.S.; Wang, Y.Y.; Peng, Y.L. Identification of a lectin gene induced in rice in response to magnaporthe grisea infection. Acta Bot. Sin. 2003, 45, 76-81.

53. Bencharki, B.; Boissinot, S.; Revollon, S.; Ziegler-Graff, V.; Erdinger, M.; Wiss, L.; Dinant, S.; Renard, D.; Beuve, M.; Lemaitre-Guillier, C.; et al. Phloem protein partners of cucurbit aphid borne yellows virus: Possible involvement of phloem proteins in virus transmission by aphids. Mol. Plant Microbe Interact. 2010, 23, 799-810. 
54. Chen, Y.; Peumans, W.J.; van Damme, E.J.M. The Sambucus nigra type-2 ribosome-inactivating protein SNA-I' exhibits in planta antiviral activity in transgenic tobacco. FEBS Lett. 2002, 516, 27-30.

55. Vandenbussche, F.; Peumans, W.J.; Desmyter, S.; Proost, P.; Ciani, M.; van Damme, E.J.M. The type-1 and type-2 ribosome-inactivating proteins from iris confer transgenic tobacco plants local but not systemic protection against viruses. Planta 2004, 220, 211-221.

56. Van Damme, E.J.M.; Lannoo, N.; Peumans, W.J. Plant lectins. Adv. Bot. Res. 2008, 48, 107-209.

57. Lannoo, N.; van Damme, E.J. Lectin domains at the frontiers of plant defense. Front. Plant Sci. 2014, 5, 397.

58. Singh, P.; Zimmerli, L. Lectin receptor kinases in plant innate immunity. Front. Plant Sci. 2013, 4, 124.

59. Vaid, N.; Pandey, P.K.; Tuteja, N. Genome-wide analysis of lectin receptor-like kinase family from arabidopsis and rice. Plant Mol. Biol. 2012, 80, 365-388.

60. Rinderle, S.J.; Goldstein, I.J.; Remsen, E.E. Physicochemical properties of amaranthin, the lectin from amaranthus-caudatus seeds. Biochemistry 1990, 29, 10555-10561.

61. Rinderle, S.J.; Goldstein, I.J.; Matta, K.L.; Ratcliffe, R.M. Isolation and characterization of amaranthin, a lectin present in the seeds of amaranthus-caudatus, that recognizes the T-antigen (or cryptic-T)-antigen. J. Biol. Chem. 1989, 264, 16123-16131.

62. Atillasoy, E.O.; Kapetanakis, A.; Itzkowitz, S.H.; Holt, P.R. Amaranthin lectin binding in the rat colon: Response to dietary manipulation. Mt. Sinai J. Med. 1998, 65, 146-153.

63. Rahbe, Y.; Sauvion, N.; Febvay, G.; Peumans, W.J.; Gatehouse, A.M.R. Toxicity of lectins and processing of ingested proteins in the pea aphid acyrthosiphon-pisum. Entomol. Exp. Appl. 1995, $76,143-155$.

64. Wu, J.; Luo, X.; Guo, H.; Xiao, J.; Tian, Y. Transgenic cotton, expressing amaranthus caudatus agglutinin, confers enhanced resistance to aphids. Plant Breed. 2006, 125, 390-394.

65. Xin, Y.; Xiangrong, Z.; Mingju, Z.; Wenchao, G.; Yingchuan, T.; Qizhong, X.; Jiahe, W. Transgenic potato overexpressing the agglutinin gene to confer aphid resistance. Crop Sci. 2011, 51, 2119-2124.

66. Helenius, A.; Trombetta, E.S.; Hebert, D.N.; Simons, J.F. Calnexin, calreticulin and the folding of glycoproteins. Trends Cell Biol. 1997, 7, 193-200.

67. Persson, S.; Wyatt, S.E.; Love, J.; Thompson, W.F.; Robertson, D.; Boss, W.F. The $\mathrm{Ca}^{2+}$ status of the endoplasmic reticulum is altered by induction of calreticulin expression in transgenic plants. Plant Physiol. 2001, 126, 1092-1104.

68. Kim, J.H.; Nguyen Hoai, N.; Ngoc Trinh, N.; Hong, S.-W.; Lee, H. Loss of all three calreticulins, CRT1, CRT2 and CRT3, causes enhanced sensitivity to water stress in arabidopsis. Plant Cell Rep. 2013, 32, 1843-1853.

69. An, Y.Q.; Lin, R.M.; Wang, F.T.; Feng, J.; Xu, Y.F.; Xu, S.C. Molecular cloning of a new wheat calreticulin gene TaCRT1 and expression analysis in plant defense responses and abiotic stress resistance. Genet. Mol. Res. 2011, 10, 3576-3585.

70. Jaouannet, M.; Magliano, M.; Arguel, M.J.; Gourgues, M.; Evangelisti, E.; Abad, P.; Rosso, M.N. The root-knot nematode calreticulin Mi-CRT is a key effector in plant defense suppression. Mol. Plant Microbe Interact. 2013, 26, 97-105. 
71. Fouquaert, E.; Peumans, W.J.; Smith, D.F.; Proost, P.; Savvides, S.N.; van Damme, E.J.M. The "old" euonymus europaeus agglutinin represents a novel family of ubiquitous plant proteins. Plant Physiol. 2008, 147, 1316-1324.

72. Fouquaert, E.; Peumans, W.J.; Vandekerckhove, T.T.M.; Ongenaert, M.; van Damme, E.J.M. Proteins with an euonymus lectin-like domain are ubiquitous in embryophyta. BMC Plant Biol. 2009, 9, 136.

73. Van Hove, J.; Fouquaert, E.; Smith, D.F.; Proost, P.; van Damme, E.J.M. Lectin activity of the nucleocytoplasmic EUL protein from Arabidopsis thaliana. Biochem. Biophys. Res. Commun. 2011, 414, 101-105.

74. Pacak, F.; Kocourek, J. Studies on phytohemagglutinins: xxv. Isolation and characterization of hemagglutinins of the spindle tree seeds (Evonymus europaea L.). Biochim. Biophys. Acta 1975, 400, 374-386.

75. Petryniak, J.; Pereira, M.E.; Kabat, E.A. The lectin of Euonymus europeus: Purification, characterization, and an immunochemical study of its combining site. Arch. Biochem. Biophys. 1977, 178, 118-134.

76. Petryniak, J.; Goldstein, I.J. Evonymus-europaea lectin. Methods Enzymol. 1987, 138, 552-561.

77. Fouquaert, E.; Van Damme, E.J. Promiscuity of the euonymus carbohydrate-binding domain. Biomolecules 2012, 2, 415-434.

78. Peumans, W.J.; Zhang, W.L.; Barre, A.; Astoul, C.H.; Balint-Kurti, P.J.; Rovira, P.; Rouge, P.; May, G.D.; van Leven, F.; Truffa-Bachi, P.; et al. Fruit-specific lectins from banana and plantain. Planta 2000, 211, 546-554.

79. Song, M.; Xu, W.; Xiang, Y.; Jia, H.; Zhang, L.; Ma, Z. Association of jacalin-related lectins with wheat responses to stresses revealed by transcriptional profiling. Plant Mol. Biol. 2014, 84, 95-110.

80. Chen, Y.; Peumans, W.J.; Hause, B.; Bras, J.; Kumar, M.; Proost, P.; Barre, A.; Rougé, P.; van Damme, E.J. Jasmonic acid methyl ester induces the synthesis of a cytoplasmic/nuclear chito-oligosaccharide binding lectin in tobacco leaves. FASEB J. 2002, 16, 905-907.

81. Lannoo, N.; Peumans, W.J.; van Pamel, E.; Alvarez, R.; Xiong, T.-C.; Hause, G.; Mazars, C.; van Damme, E.J.M. Localization and in vitro binding studies suggest that the cytoplasmic/nuclear tobacco lectin can interact in situ with high-mannose and complex $N$-glycans. FEBS Lett. 2006, 580, 6329-6337.

82. Lannoo, N.; Vandenborre, G.; Miersch, O.; Smagghe, G.; Wasternack, C.; Peumans, W.J.; Van Damme, E.J.M. The jasmonate-induced expression of the nicotiana tabacum leaf lectin. Plant Cell Physiol. 2007, 48, 1207-1218.

83. Wasternack, C.; Stenzel, I.; Hause, B.; Hause, G.; Kutter, C.; Maucher, H.; Neumerkel, J.; Feussner, I.; Miersch, O. The wound response in tomato - role of jasmonic acid. J. Plant Physiol. 2006, 163, 297-306.

84. Vandenborre, G.; Miersch, O.; Hause, B.; Smagghe, G.; Wasternack, C.; Van Damme, E.J.M. Spodoptera littoralis-induced lectin expression in tobacco. Plant Cell Physiol. 2009, 50, 1142-1155.

85. Vandenbussche, F.; Desmyter, S.; Ciani, M.; Proost, P.; Peumans, W.J.; Van Damme, E.J.M. Analysis of the in planta antiviral activity of elderberry ribosome-inactivating proteins. Eur. J. Biochem. 2004, 271, 1508-1515. 
86. Wei, G.Q.; Liu, R.S.; Wang, Q.O.; Liu, W.Y. Toxicity of two type II ribosome-inactivating proteins (cinnamomin and ricin) to domestic silkworm larvae. Arch. Insect Biochem. Physiol. 2004, 57, 160-165.

87. Shahidi-Noghabi, S.; van Damme, E.J.M.; Smagghe, G. Expression of sambucus nigra agglutinin (SNA-I') from elderberry bark in transgenic tobacco plants results in enhanced resistance to different insect species. Transgenic Res. 2009, 18, 249-259.

88. Jawhara, S.; Thuru, X.; Standaert-Vitse, A.; Jouault, T.; Mordon, S.; Sendid, B.; Desreumaux, P.; Poulain, D. Colonization of mice by candida albicans is promoted by chemically induced colitis and augments inflammatory responses through galectin-3. J. Infect. Dis. 2008, 197, 972-980.

89. Mukherjee, S.; Zheng, H.; Derebe, M.G.; Callenberg, K.M.; Partch, C.L.; Rollins, D.; Propheter, D.C.; Rizo, J.; Grabe, M.; Jiang, Q.-X.; et al. Antibacterial membrane attack by a pore-forming intestinal c-type lectin. Nature 2014, 505, 103-107.

90. Thurston, T.L.M.; Wandel, M.P.; von Muhlinen, N.; Foeglein, A.; Randow, F. Galectin 8 targets damaged vesicles for autophagy to defend cells against bacterial invasion. Nature 2012, 482, 414-418.

91. Paz, I.; Sachse, M.; Dupont, N.; Mounier, J.; Cederfur, C.; Enninga, J.; Leffler, H.; Poirier, F.; Prevost, M.-C.; Lafont, F.; et al. Galectin-3, a marker for vacuole lysis by invasive pathogens. Cell. Microbiol. 2010, 12, 530-544.

92. Xu, Y.-H.; Bi, W.-J.; Wang, X.-W.; Zhao, Y.-R.; Zhao, X.-F.; Wang, J.-X. Two novel c-type lectins with a low-density lipoprotein receptor class a domain have antiviral function in the shrimp marsupenaeus japonicus. Dev. Comp. Immunol. 2014, 42, 323-332.

93. Wang, X.-W.; Xu, Y.-H.; Xu, J.-D.; Zhao, X.-F.; Wang, J.-X. Collaboration between a soluble c-type lectin and calreticulin facilitates white spot syndrome virus infection in shrimp. J. Immunol. 2014, 193, 2106-2117.

94. Kawamura, T.; Ogawa, Y.; Aoki, R.; Shimada, S. Innate and intrinsic antiviral immunity in skin. J. Dermatol. Sci. 2014, 75, 159-166.

95. Shimojima, M.; Takenouchi, A.; Shimoda, H.; Kimura, N.; Maeda, K. Distinct usage of three C-type lectins by Japanese encephalitis virus: DC-sign, Dc-SIGNR, and LSECtin. Arch. Virol. 2014, 159, 2023-2031.

96. Zhang, Q.; Wang, X.-Q.; Jiang, H.-S.; Jia, W.-M.; Zhao, X.-F.; Wang, J.-X. Calnexin functions in antibacterial immunity of Marsupenaeus japonicus. Dev. Comp. Immunol. 2014, 46, 356-363.

97. Liu, X.; Xu, N.; Zhang, S. Calreticulin is a microbial-binding molecule with phagocytosis-enhancing capacity. Fish Shellfish Immunol. 2013, 35, 776-784.

98. Zhang, H.; Peatman, E.; Liu, H.; Feng, T.; Chen, L.; Liu, Z. Molecular characterization of three L-type lectin genes from channel catfish, Ictalurus punctatus and their responses to Edwardsiella ictaluri challenge. Fish Shellfish Immunol. 2012, 32, 598-608.

99. Huang, Y.; Tan, J.-M.; Wang, Z.; Yin, S.-W.; Huang, X.; Wang, W.; Ren, Q. Cloning and characterization of two different L-type lectin genes from the Chinese mitten crab Eriocheir sinensis. Dev. Comp. Immunol. 2014, 46, 255-266.

100. John, C.M.; Jarvis, G.A.; Swanson, K.V.; Leffler, H.; Cooper, M.D.; Huflejt, M.E.; Griffiss, J.M. Galectin-3 binds lactosaminylated lipooligosaccharides from Neisseria gonorrhoeae and is selectively expressed by mucosal epithelial cells that are infected. Cell. Microbiol. 2002, 4, 649-661. 
101. Fradin, C.; Poulain, D.; Jouault, T. Beta-1,2-linked oligomannosides from candida albicans bind to a 32-kilodalton macrophage membrane protein homologous to the mammalian lectin galectin-3. Infect. Immun. 2000, 68, 4391-4398.

102. Drickamer, K. Two distinct classes of carbohydrate-recognition domains in animal lectins. J. Biol. Chem. 1988, 263, 9557-9560.

103. Gabius, H.-J. Glycans: Bioactive signals decoded by lectins. Biochem. Soc. Trans. 2008, 36, 1491-1496.

104. Parodi, A.J. Protein glucosylation and its role in protein folding. Ann. Rev. Biochem. 2000, 69, 69-93.

105. Muller-Taubenberger, A.; Lupas, A.N.; Li, H.W.; Ecke, M.; Simmeth, E.; Gerisch, G. Calreticulin and calnexin in the endoplasmic reticulum are important for phagocytosis. EMBO J. 2001, 20, 6772-6782.

106. Guerin, R.; Beauregard, P.B.; Leroux, A.; Rokeach, L.A. Calnexin regulates apoptosis induced by inositol starvation in fission yeast. PLoS One 2009, 4, e6244.

107. Luana, W.; Li, F.; Wang, B.; Zhang, X.; Liu, Y.; Xiang, J. Molecular characteristics and expression analysis of calreticulin in chinese shrimp fenneropenaeus chinensis. Comp. Biochem. Physiol. B-Biochem. Mol. Biol. 2007, 147, 482-491.

108. Watthanasurorot, A.; Jiravanichpaisal, P.; Soderhall, K.; Soderhall, I. A calreticulin/gC1qR complex prevents cells from dying: A conserved mechanism from arthropods to humans. J. Mol. Cell Biol. 2013, 5, 120-131.

109. Wang, X.; Hinson, E.R.; Cresswell, P. The interferon-inducible protein viperin inhibits influenza virus release by perturbing lipid rafts. Cell Host Microbe 2007, 2, 96-105.

110. Sharon, N.; Lis, H. History of lectins: From hemagglutinins to biological recognition molecules. Glycobiology 2004, 14, 53R-62R.

111. Itin, C.; Schindler, R.; Hauri, H.P. Targeting of protein ERGIC-53 to the ER/ERGIC/cis-Golgi recycling pathway. J. Cell Biol. 1995, 131, 57-67.

112. Neve, E.P.A.; Svensson, K.; Fuxe, J.; Pettersson, R.F. VIPL, a VIP36-like membrane protein with a putative function in the export of glycoproteins from the endoplasmic reticulum. Exp. Cell Res. 2003, 288, 70-83.

113. Shimada, O.; Hara-Kuge, S.; Yamashita, K.; Tosaka-Shimada, H.; Li, Y.C.; Li, E.N.; Atsumi, S.; Ishikawa, H. Localization of VIP36 in the post-Golgi secretory pathway also of rat parotid acinar cells. J. Histochem. Cytochem. 2003, 51, 1057-1063.

114. Yerushalmi, N.; Keppler-Hafkemeyer, A.; Vasmatzis, G.; Liu, X.F.; Olsson, P.; Bera, T.K.; Duray, P.; Lee, B.; Pastan, I. ERGL, a novel gene related to ERGIC-53 that is highly expressed in normal and neoplastic prostate and several other tissues. Gene 2001, 265, 55-60.

115. Hauri, H.P.; Appenzeller, C.; Kuhn, F.; Nufer, O. Lectins and traffic in the secretory pathway. FEBS Lett. 2000, 476, 32-37.

116. Rini, J.M. Lectin structure. Ann. Rev. Biophys. Biomol. Struct. 1995, 24, 551-577.

117. Klumperman, J.; Schweizer, A.; Clausen, H.; Tang, B.L.; Hong, W.J.; Oorschot, V.; Hauri, H.P. The recycling pathway of protein ERGIC-53 and dynamics of the ER-Golgi intermediate compartment. J. Cell Sci. 1998, 111, 3411-3425. 
118. Vollenweider, F.; Kappeler, F.; Itin, C.; Hauri, H.P. Mistargeting of the lectin ERGIC-53 to the endoplasmic reticulum of Hela cells impairs the secretion of a lysosomal enzyme. J. Cell Biol. 1998, 142, 377-389.

119. Appenzeller, C.; Andersson, H.; Kappeler, F.; Hauri, H.P. The lectin ERGIC-53 is a cargo transport receptor for glycoproteins. Nat. Cell Biol. 1999, 1, 330-334.

120. Moussalli, M.; Pipe, S.W.; Hauri, H.P.; Nichols, W.C.; Ginsburg, D.; Kaufman, R.J. Mannose-dependent endoplasmic reticulum (ER)-Golgi intermediate compartment-53-mediated ER to Golgi trafficking of coagulation factors V and VIII. J. Biol. Chem. 1999, 274, 32539-32542.

121. Zhang, B.; Kaufman, R.J.; Ginsburg, D. LMAN1 and MCFD2 form a cargo receptor complex and interact with coagulation factor VIII in the early secretory pathway. J. Biol. Chem. 2005, 280, 25881-25886.

122. Xu, S.; Wang, L.; Wang, X.-W.; Zhao, Y.-R.; Bi, W.-J.; Zhao, X.-F.; Wang, J.-X. L-type lectin from the kuruma shrimp marsupenaeus japonicus promotes hemocyte phagocytosis. Dev. Comp. Immunol. 2014, 44, 397-405.

123. Zelensky, A.N.; Gready, J.E. The c-type lectin-like domain superfamily. FEBS J. 2005, 272, 6179-6217.

124. Yabe, R.; Iwakura, Y.; Saijo, S. The role of c-type lectin receptors c-type lectin receptors in the host defense against microbial pathogens pathogens. In Glycoscience: Biology and Medicine; Springer: Tokyo, Japan, 2014; pp. 1-10.

125. Vasta, G.R. Roles of galectins in infection. Nat. Rev. Microbiol. 2009, 7, 424-438.

126. Varki, A.; Angata, T. Siglecs-The major subfamily of i-type lectins. Glycobiology 2006, 16, $1 \mathrm{R}-27 \mathrm{R}$.

127. Crocker, P.R. Siglecs: Sialic-acid-binding immunoglobulin-like lectins in cell-cell interactions and signalling. Curr. Opin. Struct. Biol. 2002, 12, 609-615.

128. Jandus, C.; Simon, H.-U.; von Gunten, S. Targeting siglecs - a novel pharmacological strategy for immuno- and glycotherapy. Biochem. Pharmacol. 2011, 82, 323-332.

129. Avril, T.; Wagner, E.R.; Willison, H.J.; Crocker, P.R. Sialic acid-binding immunoglobulin-like lectin 7 mediates selective recognition of sialylated glycans expressed on campylobacter jejuni lipooligosaccharides. Infect. Immun. 2006, 74, 4133-4141.

130. Klaas, M.; Oetke, C.; Lewis, L.E.; Erwig, L.P.; Heikema, A.P.; Easton, A.; Willison, H.J.; Crocker, P.R. Sialoadhesin promotes rapid proinflammatory and type I IFN responses to a sialylated pathogen, Campylobacter jejuni. J. Immunol. 2012, 189, 2414-2422.

131. Crocker, P.R.; Redelinghuys, P. Siglecs as positive and negative regulators of the immune system. Biochem. Soc. Trans. 2008, 36, 1467-1471.

132. Sumner, J.B.; Howell, S.F. Identification of hemagglutinin of jack bean with concanavalin a. J. Bacteriol. 1936, 32, 227-237.

133. Oliveira, M.L.D.; Beltramini, L.M.; Simone, S.G.D.; Brumano, M.H.N.; Silva-Lucca, R.A.; Nakaema, M.K.K.; Pires, C.V.; Oliveira, M.G.D.A. Purification and partial characterization of a lectin from Caesalpinia tinctoria Domb, ex Dc fruits. Braz. J. Plant Physiol. 2003, 15, 119-122.

134. Elgavish, S.; Shaanan, B. Lectin-carbohydrate interactions: Different folds, common recognition principles. Trends Biochem. Sci. 1997, 22, 462-467.

135. Rogers, D.J.; Hori, K. Marine algal lectins-New developments. Hydrobiologia 1993, 261, 589-593. 
136. Soedjanaatmadja, U.M.S.; Subroto, T.; Beintema, J.J. Processed products of the hevein precursor in the latex of the rubber tree (heven brasiliensis). FEBS Lett. 1995, 363, 211-213.

137. Loris, R. Principles of structures of animal and plant lectins. Biochim. Biophys. Acta 2002, 1572, 198-208.

138. Transue, T.R.; Smith, A.K.; Mo, H.Q.; Goldstein, I.J.; Saper, M.A. Structure of benzyl T-antigen disaccharide bound to amaranthus caudatus agglutinin. Nat. Struct. Biol. 1997, 4, 779-783.

139. Frigerio, L.; Roberts, L.M. The enemy within: Ricin and plant cells. J. Exp. Bot. 1998, 49, 1473-1480.

140. Monzingo, A.F.; Robertus, J.D. X-ray-analysis of substrate-analogs in the ricin A-chain active-site. J. Mol. Biol. 1992, 227, 1136-1145.

141. Sampaio, A.H.; Rogers, D.J.; Barwell, C.J. A galactose-specific lectin from the red marine alga ptilota filicina. Phytochemistry 1998, 48, 765-769.

142. Jeyaprakash, A.A.; Rani, P.G.; Reddy, G.B.; Banumathi, S.; Betzel, C.; Sekar, K.; Surolia, A.; Vijayan, M. Crystal structure of the jacalin-T-antigen complex and a comparative study of lectin-T-antigen complexes. J. Mol. Biol. 2002, 321, 637-645.

143. Etzler, M.E.; Surolia, A.; Cummings, R.D. L-type lectins. In Essentials of Glycobiology; Varki, A., Cummings, R.D., Esko, J.D., Freeze, H.H., Stanley, P., Bertozzi, C.R., Hart, G.W., Etzler, M.E., Eds.; Cold Spring Harbor Laboratory Press, The Consortium of Glycobiology Editors: La Jolla, CA, USA, 2009.

144. Kabir, S.R.; Nabi, M.M.; Haque, A.; Zaman, R.U.; Mahmud, Z.H.; Abu Reza, M. Pea lectin inhibits growth of ehrlich ascites carcinoma cells by inducing apoptosis and $\mathrm{g}(2) / \mathrm{m}$ cell cycle arrest in vivo in mice. Phytomedicine 2013, 20, 1288-1296.

145. Diehl, C.; Engstrom, O.; Delaine, T.; Hakansson, M.; Genheden, S.; Modig, K.; Leffler, H.; Ryde, U.; Nilsson, U.J.; Akke, M. Protein flexibility and conformational entropy in ligand design targeting the carbohydrate recognition domain of galectin-3. J. Am. Chem. Soc. 2010, 132, 14577-14589.

146. Chouquet, A.; Paidassi, H.; Ling, W.L.; Frachet, P.; Houen, G.; Arlaud, G.J.; Gaboriaud, C. $\mathrm{X}$-ray structure of the human calreticulin globular domain reveals a peptide-binding area and suggests a multi-molecular mechanism. PLoS One 2011, 6, e17886.

147. Kozlov, G.; Bastos-Aristizabal, S.; Maeaettaenen, P.; Rosenauer, A.; Zheng, F.; Killikelly, A.; Trempe, J.-F.; Thomas, D.Y.; Gehring, K. Structural basis of cyclophilin B binding by the calnexin/calreticulin P-domain. J. Biol. Chem. 2010, 285, 35551-35557.

148. Schrag, J.D.; Bergeron, J.J.M.; Li, Y.G.; Borisova, S.; Hahn, M.; Thomas, D.Y.; Cygler, M. The structure of calnexin, an ER chaperone involved in quality control of protein folding. Mol. Cell 2001, 8, 633-644.

149. Sharon, N.; Lis, H. Legume lectins-A large family of homologous proteins. FASEB J. 1990, 4, 3198-3208.

150. Zheng, C.; Page, R.C.; Das, V.; Nix, J.C.; Wigren, E.; Misra, S.; Zhang, B. Structural characterization of carbohydrate binding by LMAN1 protein provides new insight into the endoplasmic reticulum export of factors V (FV) and viii (FVIII). J. Biol. Chem. 2013, 288, 20499-20509. 
151. Shrive, A.K.; Tharia, H.A.; Strong, P.; Kishore, U.; Burns, I.; Rizkallah, P.J.; Reid, K.B.M.; Greenhough, T.J. High-resolution structural insights into ligand binding and immune cell recognition by human lung surfactant protein D. J. Mol. Biol. 2003, 331, 509-523.

152. Hamelryck, T.W.; Poortmans, F.; Goossens, A.; Angenon, G.; van Montagu, M.; Wyns, L.; Loris, R. Crystal structure of arcelin-5, a lectin-like defense protein from phaseolus vulgaris. J. Biol. Chem. 1996, 271, 32796-32802.

153. Riera, A.S.; Daud, A.; Gallo, A.; Genta, S.; Aybar, M.; Sanchez, S. Antibacterial activity of lactose-binding lectins from Bufo arenarum skin. BIOCELL 2003, 27, 37-46.

154. Konozy, E.H.E.; Bernardes, E.S.; Rosa, C.; Faca, V.; Greene, L.J.; Ward, R.J. Isolation, purification, and physicochemical characterization of a D-galactose-binding lectin from seeds of Erythrina speciosa. Arch. Biochem. Biophys. 2003, 410, 222-229.

155. Fujimoto, Y.K.; Green, D.F. Carbohydrate recognition by the antiviral lectin cyanovirin-N. J. Am. Chem. Soc. 2012, 134, 19639-19651.

156. Barre, A.; Herve, C.; Lescure, B.; Rouge, P. Lectin receptor kinases in plants. Crit. Rev. Plant Sci. 2002, 21, 379-399.

157. Canado Viana, J.F.; Dias, S.C.; Franco, O.L.; Lacorte, C. Heterologous production of peptides in plants: Fusion proteins and beyond. Curr. Protein Pept. Sci. 2013, 14, 568-579.

158. Bebber, D.P.; Ramotowski, M.A.T.; Gurr, S.J. Crop pests and pathogens move polewards in a warming world. Nat. Clim. Chang. 2013, 3, 985-988.

159. Boyd, L.A.; Ridout, C.; O’Sullivan, D.M.; Leach, J.E.; Leung, H. Plant-pathogen interactions: Disease resistance in modern agriculture. Trends Genet. 2013, 29, 233-240.

160. Burrows, P.R.; Barker, A.D.P.; Newell, C.A.; Hamilton, W.D.O. Plant-derived enzyme inhibitors and lectins for resistance against plant-parasitic nematodes in transgenic crops. Pestic. Sci. 1998, $52,176-183$.

161. Davis, E.L.; Kaplan, D.T. Lectin binding to aqueous-soluble and body wall proteins from infective juveniles of meloidogyne species. Fundam. Appl. Nematol. 1992, 15, 243-250.

162. Marban, N.; Bess, M.; Bert, M. Evaluation of control of meloidogyne incognita and nacobbus aberrans on tomato by two leguminous plants. Rev. Nématol. 1989, 12, 409-412.

163. Guo, P.; Wang, Y.; Zhou, X.; Xie, Y.; Wu, H.; Gao, X. Expression of soybean lectin in transgenic tobacco results in enhanced resistance to pathogens and pests. Plant Sci. 2013, 211, 17-22.

164. Eisemann, C.H.; Donaldson, R.A.; Pearson, R.D.; Cadogan, L.C.; Vuocolo, T.; Tellam, R.L. Larvicidal activity of lectins on lucilia-cuprina-Mechanism of action. Entomol. Exp. Appl. 1994, 72, 1-10.

165. Machuka, J.S.; Okeola, O.G.; Chrispeels, M.J.; Jackai, L.E.N. The african yam bean seed lectin affects the development of the cowpea weevil but does not affect the development of larvae of the legume pod borer. Phytochemistry 2000, 53, 667-674.

166. Foissac, X.; Loc, N.T.; Christou, P.; Gatehouse, A.M.R.; Gatehouse, J.A. Resistance to green leafhopper (Nephotettix virescens) and brown planthopper (Nilaparvata lugens) in transgenic rice expressing snowdrop lectin (Galanthus nivalis agglutinin; GNA). J. Insect Physiol. 2000, 46, 573-583. 
167. Sun, X.; Wu, A.; Tang, K. Transgenic rice lines with enhanced resistance to the small brown planthopper. Crop Prot. 2002, 21, 511-514.

168. Fitches, E.; Gatehouse, A.M.R.; Gatehouse, J.A. Effects of snowdrop lectin (GNA) delivered via artificial diet and transgenic plants on the development of tomato moth (Lacanobia oleracea) larvae in laboratory and glasshouse trials. J. Insect Physiol. 1997, 43, 727-739.

169. Rao, K.V.; Rathore, K.S.; Hodges, T.K.; Fu, X.; Stoger, E.; Sudhakar, D.; Williams, S.; Christou, P.; Bharathi, M.; Bown, D.P.; et al. Expression of snowdrop lectin (GNA) in transgenic rice plants confers resistance to rice brown planthopper. Plant J. 1998, 15, 469-477.

170. Cox, K.D.; Layne, D.R.; Scorza, R.; Schnabel, G. Gastrodia anti-fungal protein from the orchid gastrodia elata confers disease resistance to root pathogens in transgenic tobacco. Planta 2006, 224, 1373-1383.

171. Jin, S.; Zhang, X.; Daniell, H. Pinellia ternata agglutinin expression in chloroplasts confers broad spectrum resistance against aphid, whitefly, lepidopteran insects, bacterial and viral pathogens. Plant Biotechnol. J. 2012, 10, 313-327.

172. Ueno, K.; Lim, D.J. Glycoconjugates in the chinchilla tubotympanum: A lectin histochemical study. Nihon Jibiinkoka Gakkai kaiho 1991, 94, 1826-1833.

173. Sarkar, M.; Majumder, G.C.; Chatterjee, T. Goat sperm membrane: Lectin-binding sites of sperm surface and lectin affinity chromatography of the mature sperm membrane antigens. Biochim. Biophys. Acta 1991, 1070, 198-204.

174. Sakakibara, F.; Kawauchi, H.; Takayanagi, G. Blood group B-specific lectin of Plecoglossus altivelis (Ayu fish) eggs. Biochim. Biophys. Acta 1985, 841, 103-111.

175. Khang, N.Q.; Jeanluc, G.; Johan, H. A blood group A specific lectin from the seeds of Crotalaria striata. Biochim. Biophys. Acta 1990, 1033, 210-213.

176. Monte, L.G.; Santi-Gadelha, T.; Reis, L.B.; Braganhol, E.; Prietsch, R.F.; Dellagostin, O.A.; Rodrigues e Lacerda, R.; Gadelha, C.A.A.; Conceicao, F.R.; Pinto, L.S. Lectin of Abelmoschus esculentus (okra) promotes selective antitumor effects in human breast cancer cells. Biotechnol. Lett. 2014, 36, 461-469.

177. Gonzalez-Chavarria, I.; Cerro, R.P.; Parra, N.P.; Sandoval, F.A.; Zuniga, F.A.; Omazabal, V.A.; Lamperti, L.I.; Jimenez, S.P.; Fernandez, E.A.; Gutierrez, N.A.; et al. Lectin-like oxidized LDL receptor-1 is an enhancer of tumor angiogenesis in human prostate cancer cells. PLoS One 2014, 9, e106219.

178. Ryder, S.D.; Smith, J.A.; Rhodes, J.M. Peanut lectin-A mitogen for normal human colonic epithelium and human HT29 colorectal-cancer cells. J. Natl Cancer Inst. 1992, 84, 1410-1416.

179. Aoki, T.; Kawano, J.I.; Oinuma, T.; Haraguchi, Y.; Eto, T.; Suganuma, T. Human colorectal carcinoma-specific glycoconjugates detected by pokeweed mitogen lectin. J. Histochem. Cytochem. 1993, 41, 1321-1330.

180. Nomura, K.H.; Kobayashi, R.; Hirabayashi, Y.; Fujisue-Sakai, M.; Mizuguchi, S.; Nomura, K. Involvement of blood-group-B-active trisaccharides in $\mathrm{Ca}^{2+}$-dependent cell-cell adhesion in the Xenopus blastula. Dev. Genes Evol. 1998, 208, 9-18.

181. Walker, R.A.; Hawkins, R.A.; Miller, W.R. Lectin binding and steroid-receptors in human-breast carcinomas. J. Pathol. 1985, 147, 103-106. 
182. Kabir, S. The isolation and characterization of jacalin [Artocarpus heterophyllus (jackfruit) lectin] based on its charge properties. Int. J. Biochem. Cell Biol. 1995, 27, 147-156.

183. Nelson, B.; Zhou, X.; White, M.; Hartshorn, K.; Takahashi, K.; Kinane, T.B.; Anandaiah, A.; Koziel, H. Recombinant human mannose-binding lectin dampens human alveolar macrophage inflammatory responses to influenza a virus in vitro. J. Leukoc. Biol. 2014, 95, 715-722.

184. Rajoriya, N.; Fergusson, J.R.; Leithead, J.A.; Klenerman, P. Gamma delta T-lymphocytes in hepatitis c and chronic liver disease. Front. Immunol. 2014, 5, 400.

185. Adamek, M.; Heyder, J.; Heinold, A.; Fiedler, G.; Opelz, G.; Tran, T.H. Characterization of mannose-binding lectin (MBL) variants by allele-specific sequencing of $M B L 2$ and determination of serum MBL protein levels. Tissue Antigens 2013, 82, 410-415.

186. Yazgan, I.; Noah, N.M.; Toure, O.; Zhang, S.; Sadik, O.A. Biosensor for selective detection of $E$. coli in spinach using the strong affinity of derivatized mannose with fimbrial lectin. Biosens. Bioelectron. 2014, 61, 266-273.

187. Delanghe, J.R.; Debuyzere, M.L.; Descheerder, I.K.; Faust, U.; Wieme, R.J. Activation-energy and lectin affinity-chromatography of gamma-glutamyltransferase as a marker for enzyme heterogeneity. Clin. Biochem. 1989, 22, 115-119.

188. Lescar, J.; Sanchez, J.-F.; Audfray, A.; Coll, J.-L.; Breton, C.; Mitchell, E.P.; Imberty, A. Structural basis for recognition of breast and colon cancer epitopes Tn antigen and forssman disaccharide by Helix pomatia lectin. Glycobiology 2007, 17, 1077-1083.

189. La, M.; Cao, T.V.; Cerchiaro, G.; Chilton, K.; Hirabayashi, J.; Kasao, K.; Oliani, S.M.; Chernajovsky, Y.; Perretti, M. A novel biological activity for galectin-1: Inhibition of leukocyte-endothelial cell interactions in experimental inflammation. Am. J. Pathol. 2003, 163, 1505-1515.

Sample Availability: Samples are not available from the authors.

(C) 2015 by the authors; licensee MDPI, Basel, Switzerland. This article is an open access article distributed under the terms and conditions of the Creative Commons Attribution license (http://creativecommons.org/licenses/by/4.0/). 